\title{
Solvent free Green Protocol for the Synthesis of Anti-bacterial Schiff base Dimers
}

\author{
SANGEETHA MEENAKSHISUNDARAM ${ }^{1}$ and MANOJ MANICKAM ${ }^{2 *}$ \\ 'Department of Science and Humanities, Sri Krishna College of Engineering and Technology, \\ Coimbatore, Tamil Nadu, India. \\ 2Polymer Engineering Laboratory, PSG Institute of Technology and Applied Research, \\ Coimbatore, Tamil Nadu, India. \\ ${ }^{*}$ Corresponding author E-mail: manojm@ @sgitech.ac.in, manojmbu@gmail.com mob \\ http://dx.doi.org/10.13005/ojc/350519
}

(Received: August 25, 2019; Accepted: September 29, 2019)

\begin{abstract}
A series of novel Schiff base dimers have been designed and synthesized from phthalaldehydes and various amines including aliphatic, aromatic and heterocycles by grinding at room temperature. This solvent free green protocol approach is superior to the classical approach which uses ethanol as solvent. The advantage of this new method is that wide substrates can be incorporated, very simple to carry out the reaction, easy workup with high product yield. Compounds obtained have been screened for anti-bacterial activity against nine different strains (six Gram-negative and three Gram-positive) which include E.coli, Proteus mirabilis, Klebsiella pneumonia, Proteus vulgaris, Morganella morgana, Salmonella typhi, Staphylococcus aureus, Methicillin-resistant, Enterococci faecalis. Among them, the heterocyclic groups in the side chain of the Schiff base showed better activity than the aromatic and aliphatic groups. Particularly the thiophene substituted 1,4-isomer of the Schiff base dimer showed good antibacterial activity against seven strains. Interestingly, the 1,3 isomer of the Schiff base dimer with thiophene substituent exhibited a potent antibacterial activity. An effective structure-activity relationship have also been established for the Schiff base dimers to find novel and potent anti-bacterial agents.
\end{abstract}

Keywords: Green synthesis Dimers, Schiff base, Structure-Activity Relationship, Anti-bacterial activity.

\section{INTRODUCTION}

The chemistry to design dimer molecules for the discovery and development of new drugs or leads for the drugs is proved to be a straightforward and efficient strategy. There are numerous proteins which either exist as hetero/homo dimers or become dimers and perform important functions such as cell proliferation and differentiation. For example, upon activation and binding to the ligand, the receptor tyrosine kinases VEGF and PDGF becomes homodimer and function as important cellular growth factors $^{1,2}$. Similarly, erythropoietin, a harmone which produce red blood cells binds to two receptors, thus creating a complex with receptor for its function ${ }^{3,4}$. In the same fashion, $\alpha$ and $\beta$ isoforms of the estrogen receptor form homo/hetero dimers when they bind to the ligand ${ }^{5-7}$. The molecular chaperone, Hsp90

This is an Open Access article licensed under a Creative Commons license: Attribution 4.0 International (CC- BY). Published by Oriental Scientific Publishing Company @ 2018

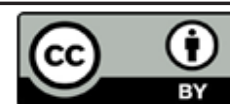


exist in the cell as homodimer and responsible for maturation of numerous signaling proteins ${ }^{8}$. The above examples insist that the therapeutic targets are mostly the dimeric proteins and therefore designing dimer molecules could be a rational strategy to interact/disrupt the protein nature.

There are natural and synthetic dimers that are more active as anti-cancer ${ }^{9}$, anti-HIV ${ }^{10}$, as well as opioidantagonists ${ }^{11,12}$ than the monomers. For examples, Indol-3-carbinol ${ }^{13}$ is commonly found in many vegetables and during digestion it is converted to its dimer diindolylmethane, which then act as an anti-cancer agent ${ }^{14,15}$. Further exploration of the dimer resulted in a novel anti-cancer agent ${ }^{16}$ (Figure 1).

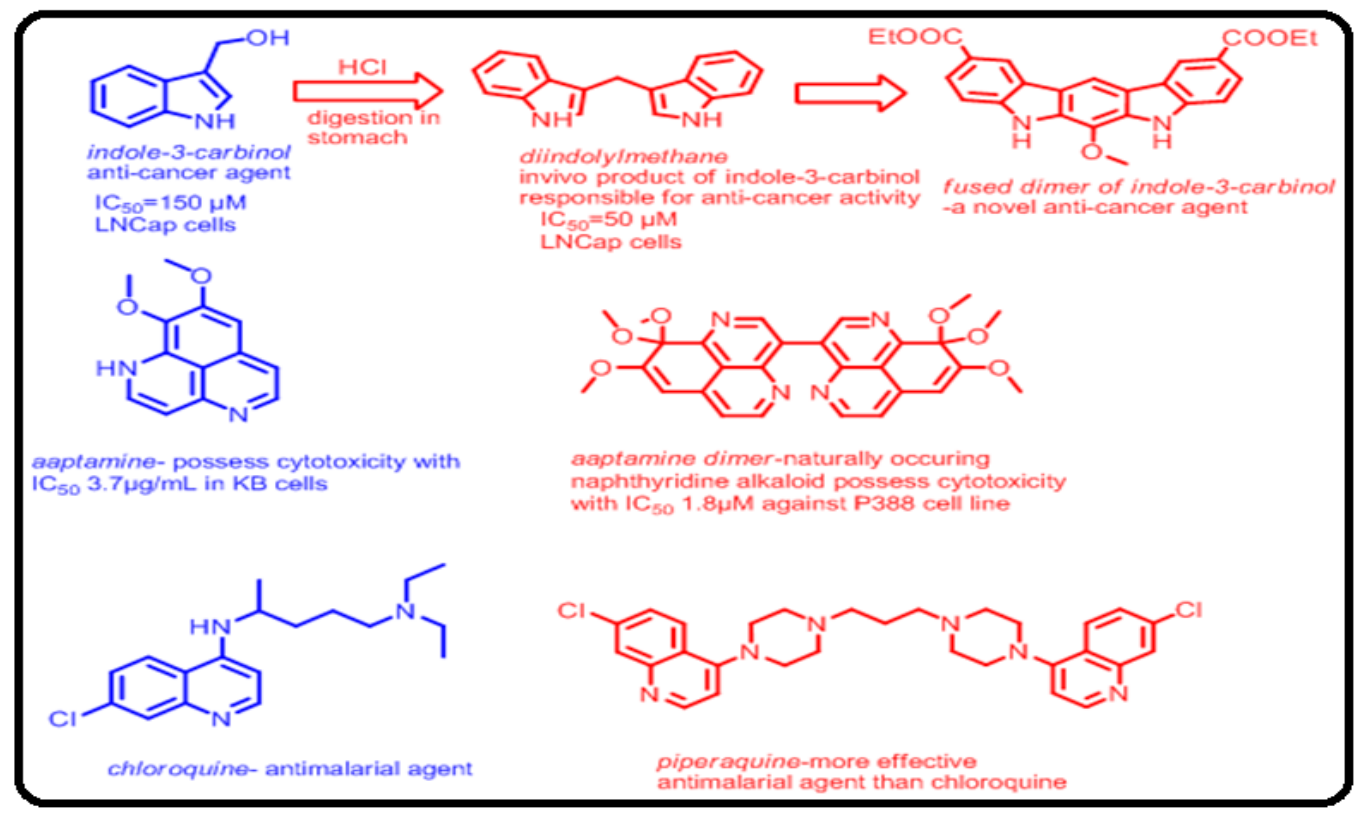

Fig. 1. Representative examples of biologically important dimers and their monomers

Aaptamine is an anti-cancer alkaloid isolated from marine sponge Aaptosaaptos ${ }^{17}$ while bis-aaptamine, isolated from the marine sponge Aaptossuberitoides showed enhanced cytotoxicity against $\mathrm{P} 388$ cell lines $\left(\mathrm{IC}_{50}\right.$ value $=$ $1.8 \mu \mathrm{M})^{18}$. Chloroquine is being replaced by its dimer, piperaquine for the treatment of malarial disease caused by Plasmodium falciparum ${ }^{19}$.

Schiff's bases are the compounds prepared form amines and aldehydes. They display antifungal ${ }^{20}$, anti-bacterial ${ }^{21}$, anti-inflammatory ${ }^{22}$, anti-viral ${ }^{23}$ activities and utilized for the synthesis of various heterocyclic compounds such as imidazoles ${ }^{24}$, imidazopyridines ${ }^{25}$ and lactams ${ }^{26}$.

Enviironmentally clean and safe chemical processes are the major goals of the chemists in the prevention of worldwide pollution ${ }^{27}$. In this regard the most sustainable method is to utilize the principles of green chemistry, which is mainly focused on the reduction or elimination chemical by products ${ }^{28,29}$.
The stable and rapid development of green chemistry is based on the environmentally safe and clean products for a long term economy of that country. Particularly pharmaceutically important Schiff bases have been prepared using water as solvent ${ }^{30}$.

In view of these above biological importance, an attempt has been made in the present work to synthesize the dimeric analogs of the Schiff bases via a green chemistry approach. All the prepared dimers of Schiff bases, were checked for antibacterial activity.

\section{EXPERIMENTAL}

Melting points of the synthesized compounds were determined by an open capillary method and are uncorrected. The IR spectra (in $\mathrm{KBr}$ pellets) were recorded on a Shimadzu FT-IR 157 spectrophotometer. ${ }^{1} \mathrm{H}$ NMR spectra were recorded on a Bruker or 300 $\mathrm{MHz}$ or $400 \mathrm{MHz}$ NMR spectrometer using DMSO- $d_{6}$ as solvent and TMS as an internal standard. Chemical shift values are given in $\delta$ scale. The purity of the compounds was checked by thin-layer chromatography 
(TLC) on silica gel plate using petroleum ether and ethyl acetate as eluting solvents.

\section{A General procedure for the preparation of} Schiff base $(5-18,12-17,19,20)$ B Classical method

To a solution of corresponding dialdehyde $(10 \mathrm{mmol})$ in ethanol $(10 \mathrm{~mL})$ corresponding amines were added and refluxed for 6 hour. After the completion of the reaction monitored by TLC, the obtained precipitate was collected by filtration and recrystallised using methanol as solvent.

\section{Green chemistry method}

The corresponding dialdehyde $(10 \mathrm{mmol})$ and the corresponding amines were added in a mortar and grinded for $10 \mathrm{~min}$ to get the Schiff base as solid. TLC showed single spot and compared with that of the compound obtained by classical method.

(N,N'E,N,N'E)-N,N'-(1,4-phenylenebis(methan-1-yl1-ylidene))dipropan-2-amine (5)

White solid. m. p. $120-122^{\circ} \mathrm{C}$. Yield: $75 \%$. IR $(\mathrm{KBr}) v_{\max }\left(\mathrm{cm}^{-1}\right): 3019,2872,1611,1042,838 .{ }^{1} \mathrm{H}$ $\operatorname{NMR}\left(\mathrm{CDCl}_{3}\right) \delta(\mathrm{ppm}): 1.27(\mathrm{~d}, \mathrm{~J}=8.02 \mathrm{~Hz}, 12 \mathrm{H}), 3.56$ (p, 2H, J = 6.80 Hz), 7.76 (s, 4H), 8.32 (s, 2H, C=NH). ${ }^{13} \mathrm{C} \mathrm{NMR}\left(\mathrm{CDCl}_{3}\right) \delta$ (ppm): 24.00, 61.80, 128.30, 138.18, 158.05. Anal. Calcd. for $\mathrm{C}_{14} \mathrm{H}_{20} \mathrm{~N}_{2}$ (216): C, 77.73, H, 9.32, N, 12.95. Found: C, 77.69, H, 9.34, N, $12.97 \%$.

(N,N'E,N,N'E)-N,N'-(1,4-phenylenebis(methan-1-yl1-ylidene))bis(3-methylbutan-1-amine) (6)

White solid. m.p. $112-114^{\circ} \mathrm{C}$. Yield: $75 \%$.IR $(\mathrm{KBr}) v_{\max }\left(\mathrm{cm}^{-1}\right): 3021,2873,1609,1041,841 .{ }^{1} \mathrm{H}$ $\operatorname{NMR}\left(\mathrm{CDCl}_{3}\right) \delta(\mathrm{ppm}): 0.95(\mathrm{~d}, \mathrm{~J}=8.02 \mathrm{~Hz}, 12 \mathrm{H}), 1.61$ (q, J = 8.00 Hz, 4H), 1.62-1.69 (m, 2H,), $3.64(\mathrm{t}, \mathrm{J}=8.02$ $\mathrm{Hz}, 4 \mathrm{H}), 7.76$ (s, 4H), 8.30 (s, 2H, C=NH). ${ }^{13} \mathrm{C}$ NMR $\left(\mathrm{CDCl}_{3}\right) \delta$ (ppm): 22.49, 25.91, 39.84, 59.99, 128.24, 138.14, 160.27. Anal. Calcd. for $\mathrm{C}_{18} \mathrm{H}_{28} \mathrm{~N}_{2}$ (272): C, 79.36, H, 10.36, N, 10.28. Found: C, 79.39, H, 10.34, N, $10.29 \%$.

(N,N'E,N,N'E)-N,N'-(1,3-phenylenebis(methan-1-yl1-ylidene))dipropan-2-amine (7)

White solid. m.p. $102-104^{\circ} \mathrm{C}$. Yield: $78 \%$.IR

$(\mathrm{KBr}) v_{\max }\left(\mathrm{cm}^{-1}\right): 3017,2871,1615,1046,837 .{ }^{1} \mathrm{H}$ NMR $\left(\mathrm{CDCl}_{3}\right) \delta(\mathrm{ppm}): 1.27(\mathrm{~d}, \mathrm{~J}=8.40 \mathrm{~Hz}, 12 \mathrm{H}), 3.51-3.59$ $(\mathrm{m}, 2 \mathrm{H}), 7.43(\mathrm{t}, \mathrm{J}=8.20 \mathrm{~Hz}, 1 \mathrm{H}), 7.79$ (dd, J = 2.20, $\mathrm{J}=8.20 \mathrm{~Hz}, 2 \mathrm{H}), 8.04(\mathrm{~s}, 1 \mathrm{H}), 8.34(\mathrm{~s}, 2 \mathrm{H}, \mathrm{C}=\mathrm{NH})$.
${ }^{13} \mathrm{C} \mathrm{NMR}\left(\mathrm{CDCl}_{3}\right) \delta(\mathrm{ppm}): 24.06,61.67,127.93$ 128.83, 129.77, 136.93, 157.98. Anal. Calcd. for $\mathrm{C}_{14} \mathrm{H}_{20} \mathrm{~N}_{2}$ (216): C, 77.73, H, 9.32, N, 12.95. Found: C, 77.73, H, 9.34, N, $12.93 \%$.

(N,N'E,N,N'E)-N,N'-(1,3-phenylenebis(methan-1-yl1-ylidene))bis(3-methylbutan-1-amine) (8)

White solid. m.p. $98-100^{\circ} \mathrm{C}$. Yield: $80 \%$.IR $(\mathrm{KBr}) v_{\max }\left(\mathrm{cm}^{-1}\right): 3011,2867,1608,1038,835 .{ }^{1} \mathrm{H}$ NMR $\left(\mathrm{CDCl}_{3}\right) \delta(\mathrm{ppm}): 0.97(\mathrm{~d}, \mathrm{~J}=8.02 \mathrm{~Hz}, 12 \mathrm{H}), 1.59-1.61$ $(\mathrm{m}, 4 \mathrm{H}), 1.62(\mathrm{~m}, 2 \mathrm{H}), 3.69(\mathrm{t}, \mathrm{J}=8.00 \mathrm{~Hz}, 4 \mathrm{H}), 7.45$ (t, J = 7.80 Hz, 1H), 7.96 (dd, $2 \mathrm{H}, \mathrm{J}=2.80, \mathrm{~J}=8.20$ $\mathrm{Hz}), 8.06$ (s, 1H), 8.37 (s, 2H, C=NH). Anal. Calcd. for $\mathrm{C}_{18} \mathrm{H}_{28} \mathrm{~N}_{2}$ (272): C, 79.36, $\mathrm{H}, 10.36, \mathrm{~N}, 10.28$. Found: C, $79.37, \mathrm{H}, 10.34, \mathrm{~N}, 10.27 \%$.

(N,N'E,N,N'E)-N,N'-(1,4-phenylenebis(methan-1-yl1-ylidene))bis(1-furan-2-yl)methyl-amine) (12) White solid. m.p. $130-132^{\circ} \mathrm{C}$. Yield: $70 \%$.IR $(\mathrm{KBr}) v_{\max }\left(\mathrm{cm}^{-1}\right): 3020,2871,1613,1044,842 .{ }^{1} \mathrm{H}$ NMR $\left(\mathrm{CDCl}_{3}\right) \delta$ (ppm): 4.80 (s, 4H), 6.29 (d, J = $\left.3.00 \mathrm{~Hz}, 2 \mathrm{H}\right)$, $6.36(\mathrm{t}, 2 \mathrm{H}, \mathrm{J}=2.40 \mathrm{~Hz}), 7.40(\mathrm{~d}, \mathrm{~J}=2.20 \mathrm{~Hz} 2 \mathrm{H}), 7.80$ (s, 4H), 8.36 (s, 2H, C=NH). ${ }^{13} \mathrm{C} \mathrm{NMR}\left(\mathrm{CDCl}_{3}\right) \delta$ (ppm): $57.18,107.71,110.43,128.59,138.06,142.39,152.08$, 162.52. Anal. Calcd. for $\mathrm{C}_{18} \mathrm{H}_{16} \mathrm{~N}_{2} \mathrm{O}_{2}$ (292): $\mathrm{C}, 73.95, \mathrm{H}$, 5.52, N, 9.58. Found: C, 73.93, H, 5.54, N, $10.92 \%$.

(N,N'E,N,N'E)-N,N'-(1,4-phenylenebis(methan-1-yl1-ylidene))bis(1-thiophen-2-yl)methyl-amine) (13) White solid. m.p. $136-138^{\circ} \mathrm{C}$. Yield: $75 \%$. IR (KBr) $v_{\max }\left(\mathrm{cm}^{-1}\right): 3024,2871,1615,1046,833$. ${ }^{1} \mathrm{H}$ NMR $\left(\mathrm{CDCl}_{3}\right) \delta$ (ppm): 5.01 (s, 4H), 7.00-7.02 (m, 4H), 7.25 (d, 2H, J = 2.40 Hz), 7.83 (s, 4H), 8.38 (s, $2 \mathrm{H}, \mathrm{C}=\mathrm{NH}) \cdot{ }^{13} \mathrm{C} \mathrm{NMR}\left(\mathrm{CDCl}_{3}\right) \delta$ (ppm): 59.24, 124.90, 125.21, 128.61, 138.07, 141.68, 161.71. Anal. Calcd. for $\mathrm{C}_{18} \mathrm{H}_{16} \mathrm{~N}_{2} \mathrm{~S}_{2}$ (324): C, 66.63, $\mathrm{H}, 4.97, \mathrm{~N}, 8.63$. Found: C, 66.63, H, 4.94, N, $8.62 \%$.

(N,N'E,N,N'E)-N,N'-(1,4-phenylenebis(methan-1-yl1-ylidene))dipyridin-2-amine) (14)

White solid. m.p. $132-134^{\circ} \mathrm{C}$. Yield: $65 \%$.IR $(\mathrm{KBr}) v_{\max }\left(\mathrm{cm}^{-1}\right): 3021,2876,1609,1044,841 .{ }^{1} \mathrm{H}$ NMR $\left(\mathrm{CDCl}_{3}\right) \delta$ (ppm): 7.22-7.24 (m, 2H), 7.37-7.43 $(\mathrm{m}, 2 \mathrm{H}), 7.77-7.81(\mathrm{~m}, 2 \mathrm{H}), 8.11(\mathrm{~s}, 4 \mathrm{H}), 8.52(\mathrm{~d}, \mathrm{~J}=$ $2.40 \mathrm{~Hz}, 2 \mathrm{H}), 9.24(\mathrm{~s}, 2 \mathrm{H}, \mathrm{C}=\mathrm{NH}) \cdot{ }^{13} \mathrm{C} \mathrm{NMR}\left(\mathrm{CDCl}_{3}\right)$ $\delta$ (ppm): 120.24, 122.26, 129.84, 137.80, 138.30, 148.19, 149.00, 162.10. Anal. Calcd. for $\mathrm{C}_{18} \mathrm{H}_{14} \mathrm{~N}_{4}$ (286): C, 75.50, H, 4.93, N, 19.57. Found: C, 75.53, H, 4.92, $\mathrm{N}, 19.55 \%$. 
(N,N'E,N,N'E)-N,N'-(1,3-phenylenebis(methan-1-yl1-ylidene))bis(1-furan-2-yl)methyl-amine) (15)

White solid. m.p. $115-117^{\circ} \mathrm{C}$. Yield: $70 \%$.IR

$(\mathrm{KBr}) v_{\max }\left(\mathrm{cm}^{-1}\right): 3019,2872,1611,1042,838 .{ }^{1} \mathrm{H}$ $\operatorname{NMR}\left(\mathrm{CDCl}_{3}\right) \delta$ (ppm): $4.79(\mathrm{~s}, 4 \mathrm{H}), 6.28$ (d, $\mathrm{J}=2.80$ $\mathrm{Hz}, 2 \mathrm{H}), 6.35$ (t, J = 2.40 Hz, 2H), 7.39 (d, J = 2.20 $\mathrm{Hz}, 2 \mathrm{H}), 7.46$ (t, J = 7.80 Hz, 1H,), 7.85 (d, J = 8.02 $\mathrm{Hz}, 2 \mathrm{H}), 8.10(\mathrm{~s}, 1 \mathrm{H}), 8.36$ (s, 2H, C=NH). ${ }^{13} \mathrm{C}$ NMR $\left(\mathrm{CDCl}_{3}\right) \delta$ (ppm): 57.03, 107.70, 110.41, 128.60, 128.97, 130.44, 136.41, 142.37, 152.13, 162.43. Anal. Calcd. for $\mathrm{C}_{18} \mathrm{H}_{16} \mathrm{~N}_{2} \mathrm{O}_{2}$ (292): C, 73.95, $\mathrm{H}, 5.52$, N, 9.58. Found: C, 73.93, H, 5.53, N, $9.52 \%$.

(N,N'E,N,N'E)-N,N'-(1,3-phenylenebis(methan-1-yl-1ylidene))bis(1-thiophene-2-yl)methyl-amine) (16) White solid. m.p. $118-120^{\circ} \mathrm{C}$. Yield: $75 \%$.IR $(\mathrm{KBr}) v_{\max }\left(\mathrm{cm}^{-1}\right): 3024,2875,1615,1047,821 .{ }^{1} \mathrm{H}$ NMR $\left(\mathrm{CDCl}_{3}\right) \delta(\mathrm{ppm}): 4.99$ (s, 4H), 6.99-7.01 (m, 4H), 7.24 (d, J = $2.40 \mathrm{~Hz}, 2 \mathrm{H}), 7.47$ (t, J = 7.80 Hz, 1H), 7.87 (dd, J = $1.80 \mathrm{~Hz}, \mathrm{~J}=8.02 \mathrm{~Hz}, 2 \mathrm{H}), 8.11$ (s, 1H), 8.39 (s, $2 \mathrm{H}, \mathrm{C}=\mathrm{NH}) \cdot{ }^{13} \mathrm{C} \mathrm{NMR}\left(\mathrm{CDCl}_{3}\right) \delta$ (ppm): 59.10, 124.88, 125.22, 126.95, 128.64, 129.01, 130.44, 136.42, 141.71. 161.67. Anal. Calcd. for $\mathrm{C}_{18} \mathrm{H}_{16} \mathrm{~N}_{2} \mathrm{~S}_{2}$ (324): C, 63.66, H, 4.97, N, 8.63. Found: C, 63.63, H, 4.95, N, $8.62 \%$.

(N,N'E,N,N'E)-N,N'-(1,3-phenylenebis(methan-1-yl1-ylidene))dipyridin-2-amine) (17)

White solid. m.p. $126-128^{\circ} \mathrm{C}$. Yield: $78 \%$. IR $(\mathrm{KBr}) v_{\max }\left(\mathrm{cm}^{-1}\right): 3020,2875,1610,1044,840 .{ }^{1} \mathrm{H}$ NMR $\left(\mathrm{CDCl}_{3}\right) \delta$ (ppm): 7.21-7.23 (m, 2H), 7.36-7.41 (m, 2H), 7.47 (t, J = 7.80 Hz, 1H), 7.78-7.82 (m, 2H), 7.87 (dd, $\mathrm{J}=1.80 \mathrm{~Hz}, \mathrm{~J}=8.02 \mathrm{~Hz}, 2 \mathrm{H}), 8.12(\mathrm{~s}, 1 \mathrm{H}), 8.53$ (d, J $=2.80 \mathrm{~Hz}, 2 \mathrm{H}), 9.24$ (s, 2H, C=NH). Anal. Calcd. for $\mathrm{C}_{18} \mathrm{H}_{14} \mathrm{~N}_{4}$ (286): C, 75.50, H, 4.93, N, 19.57. Found: C, $75.52, \mathrm{H}, 4.92, \mathrm{~N}, 19.56 \%$.

\section{Antibacterial activity}

The agar well diffusion method was employed to screen the prepared compounds for their anti-bacterial activity. All the tests were performed in duplicate. Modal values were selected as final. The compounds were weighed $(1 \mathrm{mg})$ and dissolved in DMSO (1 mL). Next, they were sterilized and filtered using a $0.45 \mu \mathrm{m}$ membrane filter. Each pathogenic microorganism was suspended in sterile saline and diluted to ca. 106 colony forming units (cfu/mL). They were swabbed on to the surface of Mueller-Hinton Agar (MHA). The wells ( $8 \mathrm{~mm}$ in diameter) were cut from the agar and $0.1 \mathrm{~mL}$ of compounds dissolved in DMSO solution was added into the well. After incubation for $24 \mathrm{~h}$ at $37^{\circ} \mathrm{C}$, all plates were examined for zones of growth inhibition. The diameter of these zones were measured in millimeters. Amoxicillin and Ceftriaxone ( $1 \mathrm{mg} / 1 \mathrm{~mL}$ in DMSO) were used as standards. The solvent DMSO was used as negative control.

\section{RESULTS AND DISCUSSION}

In the first part of the scheme 1, a series of 1,4-isomers of the Schiff bases $(5,6)$ of terephthalaldehyde and aliphatic amines were prepared. In the second part of the scheme 1 , a series of 1,3 -isomers of Schiff bases $(\mathbf{7}, \mathbf{8})$ of isophthalaldehyde and aliphatic amines were prepared. Initially the reaction was carried out in the classical route in which the aldehydes and amines were refluxed in ethanol for 3 hours. The reaction mass was poured into water to get the product as precipitate which was filtered and dried. The yields of the products were only restricted to $70-75 \%$.

In an alternate way for a green chemistry approach, the aldehydes and amines were grinded in a mortar at ambient temperature just for $10 \mathrm{~min}$ to get the product as precipitate. This solvent free green protocol approach is superior to the classical approach. Simple reaction conditions, easy, clean and safe work up and quantitative yields are the advantages of this new method. The yields were improved to $90-95 \%$. Further to explore the effect of 1,2-positional isomers of the corresponding Schiff bases, we intended to react various amines with phthalaldehyde. However, the reaction did not yield the desired product, probably due to steric factor.

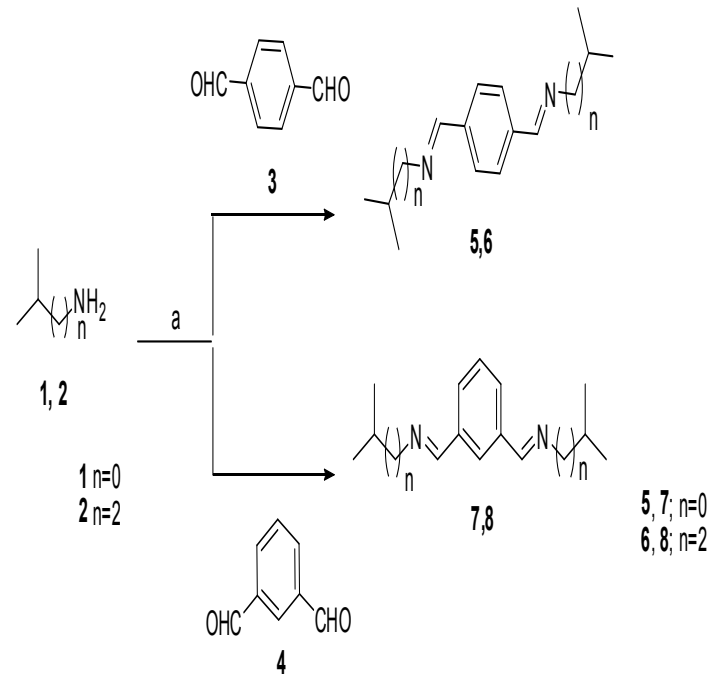

Scheme 1. Preparation of Schiff bases with aliphatic amine 
Reagents and conditions: a) Classical approach; Ethanol, reflux, 3 hour. Green approach; Grinding in mortar for 10 minutes.
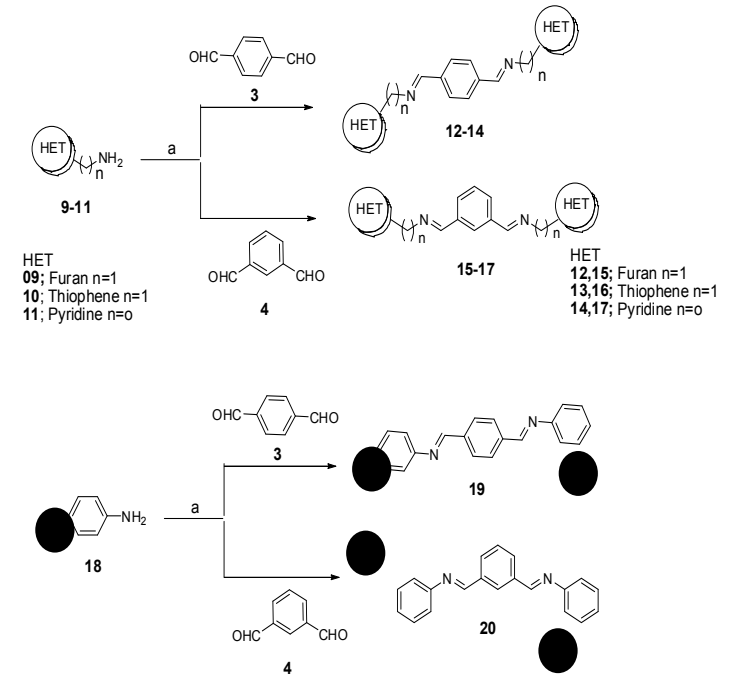

Scheme 2. Preparation of Schiff bases with aromatic and heterocyclic ring

Reagents and conditions: a) Classical approach; Ethanol, reflux, 3 hour. Green approach; Grinding in mortar for 10 minutes.

The anti-microbial activity for the prepared compounds was examined against nine different strains (six Gram-negative and three Gram-positive, Table 1). Among them, aliphatic derivatives of 1,4-positional Schiff base isomers $(5,6)$ and 1,3positional Schiff base isomers $(\mathbf{7 , 8 )}$ did not show good activity. The introduction of heterocyclic rings on both positions like furan, thiophene and pyridine showed better activity when compared to the phenyl rings itself. Among them the thiophene ring moiety 13,16 showed excellent activity. When compared to the 1,4-Schiff base isomer of thiophene (13) the 1,3-Schiff base isomer (16) exhibited the best activity along all strains except for Salmonella typhi. Fig. 2 represents the zone of inhibition of the potent compound 13 against 8 different bacteria.

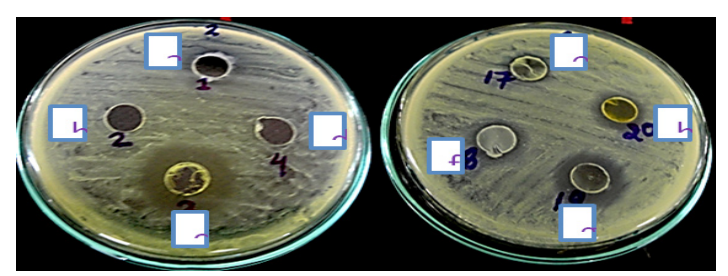

Fig. 2. Zone of inhibition of compound 13 against different bacteria a) E.coli, b) Proteus mirabilis, c) Proteus vulgaris, d) Klebsiella pneumonia, e) Morganella morgana, f), Staphylococcus aureus, g) Methicillin-resistant Staphylococcus aureus, h) Enterococci faecalis

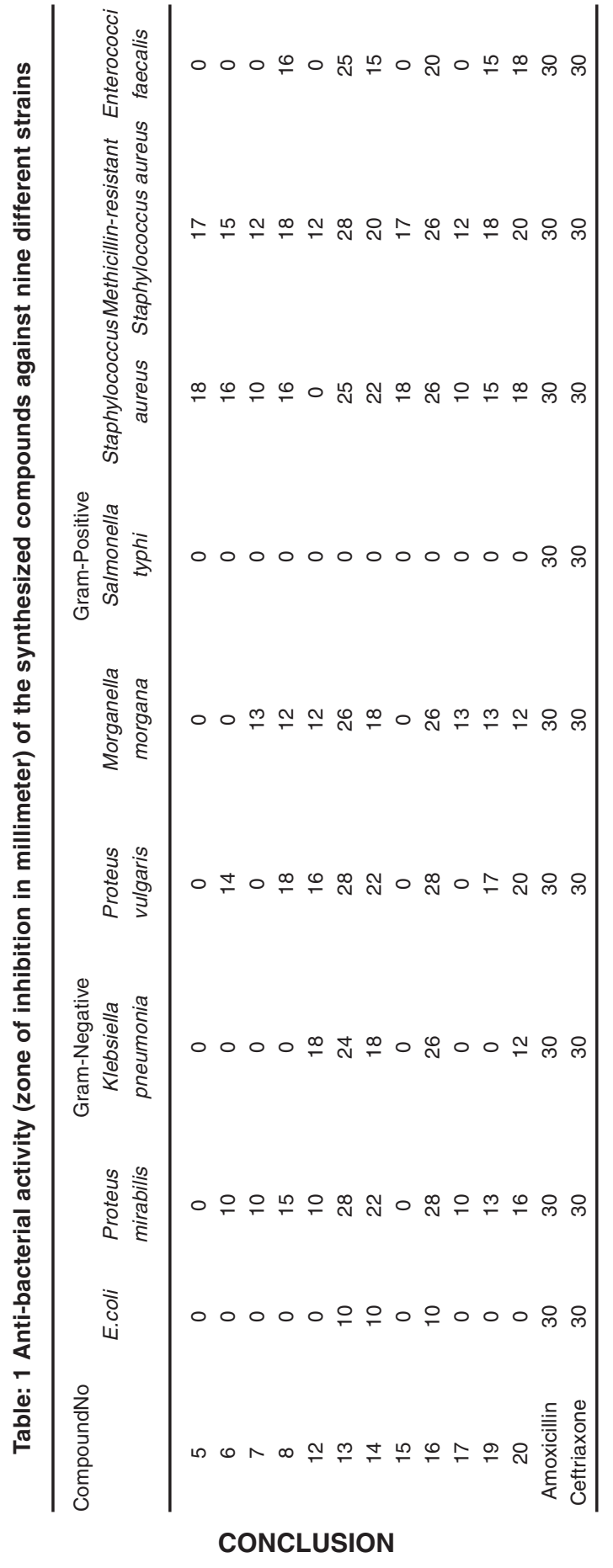

A solvent free green protocol has been designed to access the Schiff base dimers. In comparison of the classical approach in which refluxing ethanol has been used as reaction condition to get the yield of $70-75 \%$, the green synthesis utilize grinding the reactants at room temperature with 
the output of high yield $90-95 \%$. Simple reaction conditions, substrate generality, easy, safe and clean work up procedure with quantitative yields are the advantages of this novel method. With this method, a series of Schiff base dimers have been prepared. The aliphatic substituted compounds 5-8 did not exhibit good activity. However the heteroaromatic substituted Schiff bases 12-17 showed moderate to good activity. When compare to simple aromatic phenyl ring dimers 19, 20 the heteroaromatic Schiff base dimers showed potential activity. Among them, the thiophene substituted 1,4-isomer of the Schiff base 13 showed good antibacterial activity for seven strains. The 1,3 isomer 16 exhibited a potent antibacterial activity. Thus a green protocol has been designed to synthesize highly potent antibacterial Schiff base dimers.

\section{ACKNOWLEDGEMENT}

The authors thank IISc, Bangalore, Hyderabad Central University for NMR analysis.

\section{Conflicts of interest}

by the authors.

\section{REFERENCES}

1. Schlessinger, J. Cell., 2000, 103, 211-225.

2. Wiesmann, C.; Fuh, G.; Christinger, H.W.; Eigenbrot, C.; Wells, J.A.; de Vos, A. M. Cell., 1997, 91, 695-704.

3. Kossiakoff, A. A.; de Vos, A. M. Adv. Protein Chem., 1998, 52, 67-94.

4. Jiang, G.; Hunter, T. Curr. Biol., 1999, 9, R568R571.

5. Hall, J.M.; Couse, J.F.; Korach, K.S. J. Biol. Chem., 2001, 276, 36869-36872.

6. Tamrazi, A.; Carlson, K.E.; Daniels, J.R.; Hurth, K.M.; Katzenellenbogen, J.A. Mol. Endocrinol., 2002, 16, 2706-2719.

7. Brandt, M.E.; Vickery, L.E. J. Biol. Chem., 1997, 272, 4843-4849.

8. Blagg, B.S.; Kerr, T.D. Med. Res. Rev., 2006, 26, 310-338.

9. Gamage, S.A.; Spicer, J.A.; Atwell, G.J.; Finlay, G.J.; Baguley, B.C.; Denny, W.A. J. Med. Chem., 1999, 42, 2383-2393.

10. Xu, J-B.; Zhang, H.; Gan, L.S.; Han, Y.S.; Wainberg, M.A.;Yue, J-M. J. Am. Chem. Soc., 2014, 136, 7631-7633.

11. Neumeyer, J. L.; Zhang, A.; Xiong, W.; Gu, X-H.; Hilbert, J.E.; Knapp, B.I.; Negus, S.S.; Mello, N.K.; Bidlack, J. M. J. Med. Chem., 2003, 46, 5162-5170.

12. Berube, G. Curr. Med. Chem., 2006, 13, 131154.

13. Hung, W.C.; Chang, H.C. J.Agric. Food Chem., 2009, 57, 76-82.

14. Grose, K.R.; Bjeldanes, L.F. Chem. Res. Toxicol., 1992, 5, 188-193.

15. Stuab, R.E.; Onisko, B.; Bjeldanes, L.F. Chem. Res. Toxicol., 2006, 19, 436-442.

16. Chao, W.R.; Yean, D.; Amin, K.; Green, C. J. Med. Chem., 2007, 50, 3412-3415.

17. Shaari, K.; Ling, K.C.; Rashid, Z.M.; Jean, T.P.;
Abas, F.; Raof, S.M.; Zainal, Z.; Lajis, N.H.; Mohamad, H.; Ali, A.M. Mar. Drugs., 2009, 7, 1-8.

18. Liu, C.; Tang, X.; Li, P.; Li, G. Org. Lett., 2012 , 14,1994-1997.

19. Basco, L.K.; Ringwald, P. Antimicrob. Agents Chemother., 2003, 47, 1391-1394.

20. Karthikeyan, M.S.; Prasad, D.J.; Poojary, B.; Bhat, K.S.; Hollaa, B.S.; Kumari, N.S. Bioorg. Med. Chem., 2006, 14, 7482-7489.

21. Vinita, G.; Sanchita, S.; Gupta, Y.K.; Res. J. Chem. Sci., 2013, 3, 26-29.

22. Sahoo, B.M.; Dinda, S.C.; Ravi Kumar, BVV.; Panda, J.; Brahmkshatriya, P.S.; Lett. Drug Des. Discov., 2014, 11, 82-89.

23. Suresh Kumar, K.; Ganguly, S.; Veerasamy, R.; Clercq, E.D. Eur. J. Med. Chem., 2010, 45, 5474-5479.

24. Almansa, C.; Alfon, J.; de Arriba, A.F.; Cavalcanti, F.L.; Escamilla, I.; Gomez, L.A.; Miralles, A.; Soliva, R.; Bartrolı, J.; Carceller, E.; Merlos, M.; Rafanell, J.G. J. Med. Chem., 2003, 46, 3463-3475.

25. Guchhait, S.K.; Chandgude, A.L.; Priyadarshani, G. J. Org. Chem., 2012, 77, 4438-4444.

26. Naser A.W.; Majeed, A. M. J. Chem. Pharm. Res., 2015, 7, 300-306.

27. Rio Declaration on Environment and Development, Rio de Janeiro, Brazil, June 3-14, 1992 (http://www.unesco.org/education/ information/nfsunesco/pdf/RIO_E.PDF).

28. Anastas, P.T.; Warner, J.C.; Green Chemistry, Theory and Practice, Oxford University Press, Oxford., 1998.

29. Horváth, I.T. Acc. Chem. Res., 2002, 35, 685.

30. Cue, B.W.; Zhang, J. Green Chem. Lett. Rev., 2009, 2, 193-211. 